\title{
MICA Gene
}

National Cancer Institute

\section{Source}

National Cancer Institute. MICA Gene. NCI Thesaurus. Code C126959.

This gene plays a role in the immune response to stress. 